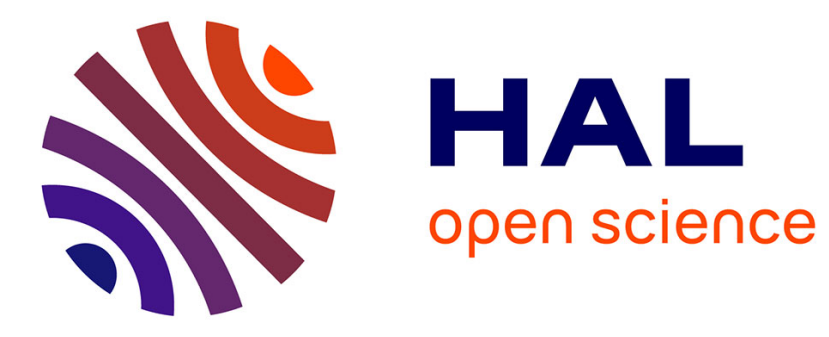

\title{
The Calcineurin Antagonist, RCAN1-4 is Induced by Exhaustive Exercise in Rat Skeletal Muscle
}

\author{
Ramin Emrani Bidi, Amélie Rébillard, Luz Lefeuvre-Orfila, Arlette \\ Gratas-Delamarche, Kelvin J. A. Davies, Josiane Cillard
}

\section{To cite this version:}

Ramin Emrani Bidi, Amélie Rébillard, Luz Lefeuvre-Orfila, Arlette Gratas-Delamarche, Kelvin J. A. Davies, et al.. The Calcineurin Antagonist, RCAN1-4 is Induced by Exhaustive Exercise in Rat Skeletal Muscle. Free Radical Biology and Medicine, 2015, 87, pp.290-299. 10.1016/j.freeradbiomed.2015.06.023 . hal-01169794

\section{HAL Id: hal-01169794 \\ https://hal-univ-rennes1.archives-ouvertes.fr/hal-01169794}

Submitted on 19 Nov 2015

HAL is a multi-disciplinary open access archive for the deposit and dissemination of scientific research documents, whether they are published or not. The documents may come from teaching and research institutions in France or abroad, or from public or private research centers.
L'archive ouverte pluridisciplinaire HAL, est destinée au dépôt et à la diffusion de documents scientifiques de niveau recherche, publiés ou non, émanant des établissements d'enseignement et de recherche français ou étrangers, des laboratoires publics ou privés. 


\section{RCAN1 and Exhaustive Exercise June 18, 2015 Revision}

\section{The Calcineurin Antagonist, RCAN1-4 is Induced by Exhaustive Exercise in Rat}

\section{Skeletal Muscle}

Ramin Emrani Bidi ${ }^{1}$, Amélie Rébillard ${ }^{2}$, Luz Lefeuvre ${ }^{2}$, Arlette Gratas-Delamarche ${ }^{2}$, Kelvin J. A. Davies ${ }^{3}$, and Josiane Cillard ${ }^{1}$

Laboratory of Movement, Sport \& Health Sciences (EA 1274), University Rennes 1, University Rennes 2, Ecole Normale Supérieure (ENS Rennes), Bruz, 35170, France

${ }^{1}$ Faculty of Pharmacy, University Rennes 1, Rennes, France

${ }^{2}$ Laboratory of Movement, Sport \& Health Sciences, University Rennes 2, ENS Rennes, France

${ }^{3}$ Ethel Percy Andrus Gerontology Center of the Leonard Davis School of Gerontology; and Division of Molecular and Computational Biology, Department of Biological Sciences, of the Dornsife College of Letters, Arts \& sciences at the University of Southern California, Los Angeles, California 90089-0191, U.S.A.

Abbreviated title: RCAN1-4 and Exhaustive Exercise

Address correspondence to:

Professeur Josiane Cillard

EA 1274 «Mouvement, Sport, Santé», Faculté de Pharmacie , 2 avenue du Pr. Léon Bernard, 35043 Rennes Cédex, FRANCE. Tel: 33 (0) 2232348 88, Fax: 33 (0) 2232348 88, josiane.cillard@univ-rennes1.fr

Reference number: 66

Number of greyscale illustrations: 9 


\section{RCAN1 and Exhaustive Exercise June 18, 2015 Revision \\ Abstract}

Aim: The aim of this work was to study regulation of the calcineurin antagonist, Regulator of Calcineurin1 protein (RCAN1), in rat skeletal muscles following exhaustive physical exercise, which is a physiological modulator of oxidative stress. Results: Three skeletal muscles, namely Extensor Digitorum Longus (EDL), gastrocnemius, and soleus were investigated. Exhaustive exercise increased RCAN1-4 protein levels in EDL and gastrocnemius, but not in soleus. Protein oxidation as an index of oxidative stress was increased in EDL and gastrocnemius, but remained unchanged in soleus. However lipid peroxidation was increased in all three muscles. CuZnSOD and catalase protein levels were increased at $3 \mathrm{Hr}$ post exercise in soleus, while they remained unchanged in EDL and gastrocnemius. Calcineurin enzymatic activity declined in EDL and gastrocnemius but not in soleus, and its protein expression was decreased in all three muscles. The level of PGC1- $\alpha$ protein remained unchanged whereas the protein expression of transcription factor NFATc4 was decreased in all three muscles. Adiponectin expression was increased in all three muscles. Conclusion: RCAN1-4 expression in EDL and gastrocnemius muscles was augmented by the oxidative stress generated from exhaustive exercise. We propose that increased RCAN1-4 expression, and the signal transduction pathways it regulates, represent important components of the physiological adaptation to exercise-induced oxidative stress.

Key words: Exhaustive exercise, skeletal muscle, oxidative damage, RCAN1, calcineurin, NFATc4, adiponectin. 


\section{RCAN1 and Exhaustive Exercise June 18, 2015 Revision Introduction}

Regulator of Calcineurin1 (RCAN1) is a member of a highly conserved family of proteins and is the endogenous and natural modulator of the serine/threonine phosphatase calcineurin [1]. The gene encoding the RCAN1 protein was previously known by several names including Adapt78, DSCR1, and MCIP1; resulting from multiple discoveries, and rediscoveries, in different cells, tissues, animals, and laboratories [2]. The three main isoforms of RCAN1 protein expressed in mammalian tissues are RCAN1-4 ( $25 \mathrm{KDa})$, RCAN1-1L ( $36 \mathrm{KDa}$ ), and RCAN1-1S ( $32 \mathrm{KDa})$; The $1 \mathrm{~L}$ and $1 \mathrm{~S}$ postscripts refer to the long and short form lengths of RCAN1 which differ in their N-terminal regions [3-5]. RCAN1-1L and RCAN1-1S are the major isoforms chronically expressed and detected in many types of tissues and cells, such as the central nervous system, heart, and skeletal muscles. Chronic RCAN1-1 overexpression is associated with pathophysiological conditions such as Down's syndrome (1.9 - fold in fetal brain tissue and up to 3 -fold within the adult hippocampus) $[6,7]$ , cancer, cardiac disorders and Alzheimer's' disease. [1, 8-11]. Conversely RCAN1-1L underexpression may be associated with the severity of symptoms in patients with Huntington's disease [12]. Interestingly it has been found that acute expression of RCAN1 isoform 4 can transiently protect cells against oxidative stress and calcium-mediated stresses [13-15]. RCAN1-4 can also be induced by other stresses, including biomechanical stress and psychological stress $[16,17]$.

Exercise can induce an oxidative stress response. Indeed the response to exercise depends on intensity, duration and type of exercise $[18,19,23]$. The beneficial effects of regular exercise have been known for a long time. During muscle contraction a mild burst in reactive oxygen species (ROS) production $[20,21]$ as well as mechanical strain, calcium flux, ATP turn-over, and intracellular oxygen pressure have all been implicated in the activation of signal transduction cascades regulating skeletal muscle adaptations to exercise [22]. Conversely, exercise when exhaustive, cause an excessive ROS generation, oxidative stress [23], an inflammatory response, and structural damage to muscle cells [24]. Skeletal muscle is 


\section{RCAN1 and Exhaustive Exercise June 18, 2015 Revision}

composed of heterogeneous fiber types that vary markedly with respect to ultrastructural morphology, contractile physiology, metabolic capabilities, speed and strength of contraction and susceptibility to fatigue [25]. Evaluating myosin ATPase in skeletal muscle led to the identification of three types of skeletal muscle fibers, namely type I, IIA, or IIB [26, 27]. Type I fibers have the slowest twitch rate and type IIB fibers have the fastest. Type IIA fibers twitch speed lie in between of type I and type IIB [27]. Soleus, a muscle with a high percentage of type I fibers has a higher mitochondrial density and oxidative capacity, a slower twitch time and a weaker twitch force. Extensor Digitorum Longus (EDL), a muscle with high percentage in type II fibers inversely has lower mitochondrial density and oxidative capacity, but more glycolytic metabolism, a faster twitch time and stronger twitch force. Interestingly resistance to oxidative stress is greatly dependent on muscle fiber composition [28]. Fast twitch fibers may be more susceptible to oxidative stress than slow twitch fibers [29].

Calcineurin is a calcium-regulated serine/threonine protein phosphatase implicated in the transduction of calcium signals elicited by the motor neurons to the myofibers $[25,30]$. Calcineurin-dependent signals are mainly transduced to the nucleus by nuclear factor of activated T cells (NFAT). NFAT is a family of five transcription factors, four of them (NFATc1, c2, c3, and c4) are regulated by calcineurin through dephosphorylation of multiple serine/threonine residues, leading to nuclear translocation and eventually DNA binding [3032]. In skeletal muscles NFAT has been proposed to cooperate with the transcription factor MEF2, downstream of calcineurin to increase the transcription of prototypical oxidative muscle fiber genes, including the transcriptional factor peroxisome proliferator-activated receptor-y co-activator (PGC 1- $\alpha$ ) [25]. PGC-1 $\alpha$ participates in the regulation of skeletal muscle metabolism, particularly energy homeostasis. It has also been reported that NFATc4 negatively regulates adiponectin expression in adipocytes [33]. Adiponectin is a circulating hormone secreted by adipose tissue, which modulates fatty acid oxidation and energy consumption in muscle [34]. Adiponectin is abundantly expressed in the sarcolemma of 


\section{RCAN1 and Exhaustive Exercise June 18, 2015 Revision}

human skeletal muscle tissue fibers [35]. Collectively, all these observations give a great interest in RCAN1-calcineurin-NFAT signaling axis in skeletal muscle and exercise.

Skeletal muscle has a large capacity to deal with and adapt to damage. The molecular mechanisms responsible for muscle recovery after damage are currently being unraveled.

The aim of this work was to study RCAN1 in skeletal muscle following exhaustive exercise as a modulator of oxidative stress. Skeletal muscle represents $40 \%$ of body mass in most mammals, hence a very important organ [36] and on the other hand, RCAN1 expression is prominent in skeletal muscle [3]. We hypothesized that oxidative damage caused by free radical generation during exhaustive exercise should provoke an increase in the oxidative responsive RCAN1 protein in skeletal muscles, which would subsequently lead to physiological adaptation through calcineurin signaling pathway. Three different skeletal muscles were investigated: Soleus, a predominantly slow twitch muscle rich in type 1 fibers; Extensor Digitorum Longus (EDL), a fast twitch muscle rich in type 2 fibers; and gastrocnemius, a 'mixed muscle' which contains both type 1 and type 2 fibers.

\section{Materials and Methods}

Animals: Thirty two male Wistar rats, each seven weeks old, were purchased from Elevage Janvier (Bretagne, France) and quarantined for one week followed by one week of familiarization. They were housed in ordinary cages at room temperature of $25 \pm 3^{\circ} \mathrm{C}$ with a 12Hr light and dark cycle. They had ad libitum access to food in the form of dry pellets and water. They were randomly divided into four groups of eight rats. Three groups of experimental rats, submitted to an Exhaustive exercise protocol [20], and then sacrificed either immediately or $3 \mathrm{Hr}$ or $6 \mathrm{Hr}$ after exercise. A control group of eight rats without exercise were sacrificed under the same conditions.

Exercise Protocols and Specimen Collection: Rats weighing $315 \pm 15 \mathrm{~g}$ were exercised until exhaustion following a treadmill protocol [20]. Briefly, we used a progressive intensity, motor 


\section{RCAN1 and Exhaustive Exercise June 18, 2015 Revision}

driven, treadmill exercise, consisting of an initial bout of $5 \mathrm{~min}$ at $11 \mathrm{~m} / \mathrm{min}$ with consecutive $3 \mathrm{~m} / \mathrm{min}$ increments every $5 \mathrm{~min}$ at a constant grade of $15 \%$. Exhaustion was defined as the inability of a rat to right itself when being laid on its side, due to extreme physical exerciseassociated fatigue. The running time before exhaustion was between 60 minutes \pm 5 minutes depending on the animals. Control rats were not exercised. Rats were anaesthetized with intraperitoneal injection of ketamine- $\mathrm{HCl}$ and xylazine cocktail $(100 \mathrm{mg} / \mathrm{kg}$ and $5 \mathrm{mg} / \mathrm{kg}$, respectively). Three different skeletal muscles were harvested: Soleus, Extensor Digitorum Longus (EDL), and gastrocnemius. The samples were frozen immediately and stored at $-80^{\circ} \mathrm{C}$ until used.

The entire experiment and all animal care procedures were conducted in compliance with the guidelines established by the "animal experimentation ethic committee", University of Rennes1, France (CREEA) with authorization number: 35100, following the use of the French Farming Minister's Guide for the Care and Use of Laboratory Animals, and the formal approval documents may be obtained upon request.

Sample Preparation for Immunoblot Analysis: 100mg of each muscle was homogenized in $1 \mathrm{ml}$ buffer using a Polytron tissue grinder, and then sonicated using Vibracell sonicator. The buffer contained $200 \mathrm{mM}$ Tris - $\mathrm{PH} 7.4,20 \mathrm{mM} \mathrm{NaCl}, 0.5 \%$ TritonX-100, and protease inhibitor cocktail tablets (Roche Applied Science, Penzberg, Germany). The homogenate was spun at $12000 \mathrm{~g}$ for $15 \mathrm{~min}$ at $4^{0} \mathrm{C}$. For conventional western blotting, using Bradford's assay [37] $100 \mu \mathrm{g}$ of total protein was measured in the homogenate and was resolved by $12.5 \%$ SDS-PAGE. For adiponectin immunoblot, electrophoresis runs under non-denaturing and non-reducing condition. The tissue homogenate was mixed with loading buffer deprived of SDS and $\beta$-mercaptoethanol and directly loaded on $5 \%$ polyacrylamide gel deprived of SDS. The proteins were electrophoretically transferred to nitrocellulose membranes (BioRad, Hercules, USA), and immunoblotted with the relevant primary antibodies (details of antibodies in the next paragraph). An overnight application of the primary antibodies in nonfat milk-TBS solution at $4^{0} \mathrm{C}$ was followed by extensive washing in $0.05 \%$ TBS-Tween. 


\section{RCAN1 and Exhaustive Exercise June 18, 2015 Revision}

Blots then were incubated with secondary goat anti-rabbit (IRDye ® $800 \mathrm{CW} 2: 10,000$ ) or goat anti-mouse (IRDye ® 680 2:10,000) HP-conjugated antibodies in nonfat milk-TBS solution. The Li-Cor Odyssey Infrared Imaging Detection System was used for visualization of protein bands. Quantitative densitometry analysis was carried out using Image Gauge V4.0 software. In all Immunoblots, Hsc $70(72 \mathrm{KDa})$, a constitutively expressed chaperone variant of heat shock protein 70 , which is not modulated by physical exercise, was used as an equal loading control [38].

Antibodies: The "common" RCAN1 antibody directed against invariant exon7 of RCAN1 which recognizes all isoforms of RCAN1, was generously provided by Prof. Kelvin J.A. Davies (USC, Los Angles, USA) . Calcineurin, adiponectin and catalase antibodies were purchased from sigma Aldrich (Saint-Louis, USA). PGC1- $\alpha$ antibody was purchased from cell signaling (Danvers, USA). All NFAT antibodies were purchased from Abcam (Cambridge, $U K)$. CuZnSOD, MnSOD and GPx antibodies were purchased from Enzo Life Science (Farmingdale, USA). All of these antibodies were diluted in skimmed milk or BSA solution in the ratio recommended by their producers.

Protein Oxidation: The procedure is based on the spectrophotometric detection of proteinhydrazone formed by the reaction of dinitrophenylhydrazine (DNPH) with protein carbonyl moieties [39]. Briefly $100 \mathrm{mg}$ of the tissues were homogenized in $1 \mathrm{ml}$ of the same homogenization buffer used for immunoblot, containing $1 \mathrm{mM}$ EDTA and $0.1 \%$ digitonin. Samples were centrifuged at $10000 \mathrm{~g}$ at $4^{\circ} \mathrm{C}$ for $15 \mathrm{~min}$ and the supernatants were checked for nucleic acid contamination. Contaminations were eradicated using $1 \%$ streptomycin following centrifugation at $4000 \mathrm{~g}$ for $15 \mathrm{~min}$ at room temperature. Two doses of $300 \mu \mathrm{l}$ of the supernatant from each muscle were transferred to two plastic tubes, one as Sample (S), other one as Control (C).

$1200 \mu \mathrm{l}$ of DNPH was added to each of the S and $1200 \mu \mathrm{l}$ of $2.5 \mathrm{M}$ HCL in each C tube and were incubated at room temperature in dark for 15 minutes. $1 \mathrm{ml}$ of $20 \%$ trichloroacetic acid was added to each solution, vortexed and incubated on ice for 5 min following a 


\section{RCAN1 and Exhaustive Exercise June 18, 2015 Revision}

centrifugation at $10000 \mathrm{~g}$ for $10 \mathrm{~min}$ at $4^{\circ} \mathrm{C}$. The pellet was next suspended in $1 \mathrm{ml} 10 \%$ trichloroacetic acid (following another centrifugation at $10000 \mathrm{~g}$ for $10 \mathrm{~min}$ at $4^{\circ} \mathrm{C}$ ). The pellet was manually suspended with a spatula in $1 \mathrm{ml}$ ethanol/ethyl acetate solution (1:1 v/v ratio), vortexed thoroughly and then centrifuged at $10000 \mathrm{~g}$ for $10 \mathrm{~min}$ at $4^{\circ} \mathrm{C}$, three consecutive times. Finally the pellet was resuspended in $750 \mu \mathrm{l}$ of $6 \mathrm{M}$ guanidine hydrochloride (sigma Aldrich, Saint-Louis, USA) by vortexing following a spin at $10000 \mathrm{~g}$ for $10 \mathrm{~min}$ at $4^{\circ} \mathrm{C}$. The absorbance of the supernatant was measured at $365 \mathrm{~nm}$.

Lipid Peroxidation: A rough estimate of lipid peroxidation was obtained by measuring the formation of thiobarbituric acid reactive substances [40, 41]. For these assays, 100mg of each muscle was homogenized in $1 \mathrm{ml}$ of the same buffer used for immunoblotting, containing $0.1 \mathrm{mM}$ butylated hydroxytoluene. Two $\mathrm{ml}$ of thiobarbituric acid solution containing $0.350 \mathrm{~g}$ thiobarbituric acid (purchased from sigma Aldrich, Saint-Louis, USA), and 15g trichloroacetic acid in sufficient quantity of $0.25 \mathrm{~N}$ HCL to make up the final volume to $100 \mathrm{ml}$ solution, was added to $1 \mathrm{ml}$ of each muscle homogenate. This mixture was vortexed in a glass test tube for one minute and was incubated in water bath at $100^{\circ} \mathrm{C}$ for 15 minutes. The tubes were cooled down to room temperature and were kept on ice for 5 minutes. The colored solution containing thiobarbituric acid-adducts was extracted using $3 \mathrm{ml}$ of $\mathrm{n}$-buthanol following a spin at 3,000 rpm for $10 \mathrm{~min}$. The organic phase was collected to measure its absorbance at $535 \mathrm{~nm}$. Lipid peroxide levels are expressed in terms of MDA equivalents, determined by constructing a calibration curve using standard amounts of MDA.

Calcineurin Enzymatic Activity Assay: Calcineurin enzymatic activity assay was carried out using calcineurin Cellular Activity Assay Kit (Enzo life science, Farmingdale, USA). The method is based on the complex formed between malachite green molybdate and free orthophosphate under acidic condition [42, 43]. Briefly the free phosphatases in the homogenate were removed using gel filtration column and the total phosphatase activity, EGTA buffer phosphatase activity, okadaic acid (OA) phosphatase activity and a combination of OA and EGTA buffer activity were carried out for each sample under the same condition 


\section{RCAN1 and Exhaustive Exercise June 18, 2015 Revision}

and in the same 96 well plate. The standard graph of $\mathrm{PO}_{4}$ versus optical density at $620 \mathrm{~nm}$ was drawn to calculate the released phosphate for each set of the reaction to determine the calcineurin activity.

Statistical Analysis: Statistical analysis, ANOVA and, when appropriate, post-hoc Dunnet's test were undertaken using SigmaStat software. All values were expressed as mean \pm S.D. $\mathrm{P}<0.05$ was set as the levels for significance testing.

\section{Results}

Modulation of the Levels of RCAN1 Isoforms by Exhaustive Exercise: RCAN 1-1L, RCAN1-1S and RCAN1-4 were detected in all three muscles. The three RCAN1 isoforms were differentially expressed in the three skeletal muscles with the protein content of all RCAN1 isoforms being highest in soleus. RCAN1-1L was the highest-expressed isoform in all muscles.

Exhaustive exercise differentially modulated the RCAN1 isoforms. RCAN1-4 increased significantly $3 \mathrm{Hr}$ after exercise until $6 \mathrm{Hr}$ in $\mathrm{EDL}$ and gastrocnemius, but no significant changes were seen in soleus after exercise. RCAN1-1L and -1S were not affected by exercise in any muscle [Fig.1].

Effect of Exhaustive Exercise on Oxidative Stress Markers: Protein carbonyl levels, as a marker of protein oxidation, showed no significant change in soleus muscle throughout the post exercise time, or in control rats. In contrast to this, protein carbonyls increased significantly in EDL and gastrocnemius at $3 \mathrm{Hr}$ post exercise, and continued increasing until $6 \mathrm{Hr}$ post exercise [Fig. 2A].

The levels of thiobarbituric acid (TBA)-reactive materials, as a very rough potential indicator of lipid peroxidation, increased in all three muscles immediately after exhaustive exercise $(0 \mathrm{Hr})$ compared to control rats [Fig. 2B]. TBA levels in EDL and gastrocnemius increased 


\section{RCAN1 and Exhaustive Exercise June 18, 2015 Revision}

continuously up to $6 \mathrm{Hr}$ post exercise. In soleus, however, TBA levels after increasing immediately after exhaustive exercise, then remained almost unchanged from $0 \mathrm{Hr}$ group until $6 \mathrm{Hr}$.

\section{Effect of Exhaustive Exercise on the Levels of Antioxidant Enzyme Proteins in Rat Skeletal}

Muscles: CuZnSOD [Fig. 3] and Catalase [Fig. 4] protein levels were modulated in response to exhaustive exercise only in soleus muscle. Both CuZnSOD and Catalase protein levels increased significantly in soleus at $3 \mathrm{Hr}$ post-exercise and continued to increase until $6 \mathrm{Hr}$ postexercise [Figs 3 and 4]. In contrast, Glutathione peroxidase (GPx) and MnSOD protein levels were not affected by exhaustive exercise [Fig. 5].

Effect of Exhaustive Exercise on both the Levels and Activity of Calcineurin: The levels of calcineurin protein decreased from controls to $6 \mathrm{Hr}$ post exercise in all three muscles. This decline was significant at $3 \mathrm{Hr}$ post exercise in soleus muscles, and at $6 \mathrm{Hr}$ post exercise in EDL and gastrocnemius muscle.

Beside the down-regulation in the levels of calcineurin after exhaustive physical exercise, calcineurin enzymatic assay showed a significant decrease at $3 \mathrm{Hr}$ post exercise in EDL and gastrocnemius muscles but no change was observed in soleus muscle [Fig.6].

PGC 1- $\alpha$ may not Respond to a Single Bout of Exhaustive Exercise: Although there was an apparent, and consistent, trend towards increased levels of transcriptional factor peroxisome proliferator-activated receptor- $ү$ co-activator (PGC 1- $\alpha$ ) protein in all three muscles after a single bout of exhaustive exercise, the increases did not reach statistical significance. It is possible that a single bout of exercise is not sufficient to significantly upregulate PGC 1 - $\alpha$ [Fig.7].

NFATc4 is Down-regulated in All Muscles After Exhaustive Exercise: Of all four NFAT protein isoforms, the only variant modified by exhaustive exercise was NFATc4, which showed a significant decrease at $6 \mathrm{Hr}$ post exercise in all three muscles [Fig.8]. NFATc4 is the only necessary isoform for transcription of MyHC-2B which is the fastest fiber amongst 4 


\section{RCAN1 and Exhaustive Exercise June 18, 2015 Revision}

types of muscle fibers [44] and is the only isoform of NFAT which is not tightly associated to the immune system but is fairly ubiquitous [45].

Adiponectin is Increased in All Muscles After Exhaustive Exercise: The protein level of adiponectin was increased in all three muscles $6 \mathrm{Hr}$ after a single bout of exhaustive exercise [Fig.9].

\section{Discussion}

The major finding of our experiments is that a single bout of exhaustive exercise modulates only the expression of RCAN1 isoform 4, in rat EDL and gastrocnemius muscles. We also observed a much lower basal level of RCAN1-4 protein compared to RCAN1-1L protein, which has been previously reported [46]. Even though the content of RCAN1-4 was highest in soleus, exercise did not modulate significantly the expression of RCAN1-4 in this muscle. In our experiment, exercise did not have any effect on other RCAN1 isoforms, but it has been reported that the pattern of expression and the roles of different RCAN1 isoforms might be independent from each other $[46,47]$. An increase in modulatory calcineurin-interacting protein 1(MCIP1) has been reported in human skeletal muscle during recovery from eccentric exercise [48].

RCAN1-4 is known to be a cytoprotective element in the adaptive response to oxidative stress $[13,14]$, whereas altered RCAN1-1 expression has been associated with pathologies $[1,8-11]$. Exhaustive exercise can cause cell damage $[21,24,49]$ through increased oxidative stress [50, 51]. We observed clear evidence of muscle oxidative damage using protein oxidation (carbonyls) and lipid peroxidation markers [52-54]. Protein carbonyls were significantly increased in EDL (55\%) and gastrocnemius $(48 \%) 3 \mathrm{Hr}$ after exercise, yet no significant change in protein carbonyls was observed in soleus, whilst lipid peroxidation increased significantly in all three muscles after exercise. These observations suggest that the protein 


\section{RCAN1 and Exhaustive Exercise June 18, 2015 Revision}

levels of RCAN1-4 were increased in EDL and gastrocnemius to protect these muscles from oxidative stress. Indeed in another experiment, diabetic and non diabetic rats were trained for 8 weeks and then submitted to exhaustive exercise. Oxidative stress markers remained unchanged and the protein RCAN1-4 did not increase in EDL, gastronecmius and soleus (unpublished data).

The fact that RCAN1-4 remained unchanged in soleus may suggest that soleus is protected from oxidative stress through alternative mechanisms. Interestingly, in this regard, we observed a net increase in the antioxidant SOD and catalase protein levels in soleus, but no change in EDL or gastrocnemius. Soleus in which large number of fibers are of the slow twitch variety, works longer than other muscles in endurance exercise [55], which may mean that it experiences more oxidative stress than the other muscle groups. Slow twitch fibers have typically more robust antioxidant defenses [28, 29], and produces more superoxide and hydrogen peroxide than the other muscles via leakage of electrons from mitochondrial oxidative phosphorylation $[49,56,57]$. The increase in catalase and CuZnSOD is a possible mechanism to explain why no increase in protein carbonyl was observed post exercise in soleus.

Since RCAN1 proteins negatively regulate the activity of calcineurin, a decrease in calcineurin enzymatic activity is expected when RCAN1 is upregulated, and this was observed in our experiments. In EDL and gastrocnemius where RCAN1-4 levels increased significantly post-exercise, the enzymatic activity of calcineurin decreased significantly. In contrast, calcineurin enzymatic activity remained unchanged in soleus where the protein level of RCAN1-4 also remained unchanged.

It has been shown that PGC-1 $\alpha$ is more expressed in oxidative fibers [58]. As expected in our experiment the protein level of PGC-1 $\alpha$ was highest in the soleus. Normally glycolytic fibers express lower levels of PGC-1 $\alpha$ and they exhibit a greater degree of atrophy than oxidative fibers in disease or systemic models of muscle atrophy [59-61]. It has been reported that several weeks of endurance exercise training may induce PGC-1 $\alpha$ mRNA, mitochondrial 


\section{RCAN1 and Exhaustive Exercise June 18, 2015 Revision}

biogenesis and mitochondrial content independent of calcineurin activation [62-64]. In the single bout of exhaustive exercise used in our experiments, in which animals reached exhaustion after around one hour of exercise, there was a clear decrease in calcineurin activity (due to RCAN1 upregulation) but increases in PGC-1 $\alpha$ levels failed to reach statistical significance, despite displaying a clear and consistent upward trend. We conclude that more than a single bout of exercise is required for a truly significant difference in PGC- $1 \alpha$ and mitochondrial biogenesis.

NFATc4 was down-regulated post exercise in all three muscles. RCAN1 can repress NFAT signaling via inhibition of calcineurin [31], but can also be activated via a calcineurin-NFAT pathway [25, 42], thereby forming a negative feedback loop for RCAN1 gene regulation. It is known that all NFATs are regulated by calcineurin [30, 32, 42] and NFAT negatively regulates the expression of adiponectin [33]. Indeed, we observed a net increase in adiponectin expression in all three muscles $6 \mathrm{Hr}$ after a single bout of exhaustive exercise, where NFATc4 was downregulated. It has been recently reported that 6-month exercise training induced a 7 folds increase in adiponectin mRNA in rat skeletal muscle and a 2.1 fold increase in adiponectin protein content in membrane extracts of rat skeletal muscle [65]. Therefore, the increase in adiponectin expression following NFATc4 down-regulation is probably a mechanism to increase fatty acid oxidation and energy consumption in skeletal muscles.

\section{Conclusion}

RCAN1 is the natural endogenous regulator of calcineurin. Its regulation could help in managing many oxidative stress related pathophysiological complications like Alzheimer disease and diabetes mellitus. Indeed pharmacological inhibitors of calcineurin notably Cyclosporin A and Tacrolimus (FK 506) are associated with profound metabolic side effects 


\section{RCAN1 and Exhaustive Exercise June 18, 2015 Revision}

including diabetogenic effects and dyslipidemia [66]. We propose that RCAN1-4 expression in response to oxidative damage induced by exhaustive exercise inhibits calcineurin signaling pathway resulting in a decrease in NFATc4 and an increase in adiponectin. This mechanism represents an important component of the physiological adaptation to exercise. Thus, RCAN1-4 may offer a promising scope for non-pharmacological management of such disorders through physical activity, with the prospect of lesser undesirable side effects than the drugs.

\section{Acknowledgments:}

This work was partly supported by Sepehr Shams Company, Mashhad, Iran.

The authors would like to thank all the members of EA1274 (M2S) laboratory in University of Rennes 1, Rennes 2 and ENS Rennes - France for their support and assistance with this project. Special thanks also go to Frédéric Derbré, Assistant professor in M2S laboratory, ENS Rennes for his advice and counseling about western blot densitometry analysis and Dany Saligaut, research technician for her technical assistance. 


\section{RCAN1 and Exhaustive Exercise June 18, 2015 Revision}

\section{Author disclosure statement}

No competing financial interests exist. 


\section{RCAN1 and Exhaustive Exercise June 18, 2015 Revision}

\section{List of Abbreviations:}

ANOVA: analysis of variance

CREEA: regional committee on ethics and animal experimentation

DSCR1: down syndrome critical region gene 1

EDL: extensor digitorum longus

EDTA: ethylenediaminetetraacetic acid

EGTA: ethylene glycol-bis(2-aminoethylether)-N,N,N',N'- tetraacetic acid

GPx: glutathione peroxidase

HCL: hydrochloric acid

HCS 70: heat shock $72 \mathrm{KDa}$

HP: hematoporphyrin

$\mathrm{Hr}$ : hour

MCIP1: modulatory calcineurin-interacting protein 1

MDA: malondialdehyde

MEF2: myocyte enhancer factor-2

MyHC-2B: myosin heavy chain $2 b$

$\mathrm{NaCl}$ : sodium chloride

DNPH: 2,4-dinitrophenylhydrazine

NFAT: nuclear factor of activated T-cells

OA: okadaic acid

PGC1- $\mathrm{a} \square$ : peroxisome proliferator-activated receptor gamma coactivator 1-alpha

PO4: phosphate

RCAN1: regulator of calcineurin 1

ROS: reactive oxygen species

SDS: sodium dodecyl sulfate

SDS-PAGE: sodium dodecyl sulfate polyacrylamide gel electrophoresis 


\section{RCAN1 and Exhaustive Exercise June 18, 2015 Revision}

SEM: Standard error of the mean

CuZnSOD: copper zinc superoxide dismutase

MnSOD: manganese superoxide dismutase

TBA: thiobarbituric acid

TBS: tris-buffered saline

\section{References:}

1. Fuentes, J. J.; Genesca, L.; Kingsbury, T. J.; Cunningham, K. W.; Perez-Riba, M.; Estivill, X.; de la Luna, S. DSCR1, overexpressed in Down syndrome, is an inhibitor of calcineurin-mediated signaling pathways. Hum. Mol. Genet. 9:1681-1690; 2000.

2. Davies, K. J.; Ermak, G.; Rothermel, B. A.; Pritchard, M.; Heitman, J.; Ahnn, J.; Henrique-Silva, F.; Crawford, D.; Canaider, S.; Strippoli, P.; Carinci, P.; Min, K. T.; Fox, D. S.; Cunningham, K. W.; Bassel-Duby, R.; Olson, E. N.; Zhang, Z.; Williams, R. S.; Gerber, H. P.; Perez-Riba, M.; Seo, H.; Cao, X.; Klee, C. B.; Redondo, J. M.; Maltais, L. J.; Bruford, E. A.; Povey, S.; Molkentin, J. D.; McKeon, F. D.; Duh, E. J.; Crabtree, G. R.; Cyert, M. S.; de la Luna, S.; Estivill, X. Renaming the DSCR1/Adapt78 gene family as RCAN: regulators of calcineurin. FASEB J. 21:3023$3028 ; 2007$.

3. Fuentes, J. J.; Pritchard, M. A.; Estivill, X. Genomic organization, alternative splicing, and expression patterns of the DSCR1 (Down syndrome candidate region 1) gene. Genomics 44:358-361; 1997. 


\section{RCAN1 and Exhaustive Exercise June 18, 2015 Revision}

4. Genesca, L.; Aubareda, A.; Fuentes, J. J.; Estivill, X.; De La Luna, S.; Perez-Riba, M. Phosphorylation of calcipressin 1 increases its ability to inhibit calcineurin and decreases calcipressin half-life. Biochem. J. 374:567-575; 2003.

5. Wu, Y.; Song, W. Regulation of RCAN1 translation and its role in oxidative stressinduced apoptosis. FASEB J. 27:208-221; 2013.

6 Fuentes, J. J.; Pritchard, M. A.; Planas, A. M.; Bosch, A.; Ferrer, I.; Estivill, X. A new human gene from the Down syndrome critical region encodes a proline-rich protein highly expressed in fetal brain and heart. Hum. Mol. Genet. 4:1935-1944; 1995.

7. Ermak, G.; Morgan, T. E.; Davies, K. J. Chronic overexpression of the calcineurin inhibitory gene DSCR1 (Adapt78) is associated with Alzheimer's disease. J. Biol. Chem. 276:38787-38794; 2001.

8. Baek, K. H.; Zaslavsky, A.; Lynch, R. C.; Britt, C.; Okada, Y.; Siarey, R. J.; Lensch, M. W.; Park, I. H.; Yoon, S. S.; Minami, T.; Korenberg, J. R.; Folkman, J.; Daley, G. Q.; Aird, W. C.; Galdzicki, Z.; Ryeom, S. Down's syndrome suppression of tumour growth and the role of the calcineurin inhibitor DSCR1. Nature 459:1126-1130; 2009.

9. Cook, C. N.; Hejna, M. J.; Magnuson, D. J.; Lee, J. M. Expression of calcipressin1, an inhibitor of the phosphatase calcineurin, is altered with aging and Alzheimer's disease. J. Alzheimers Dis. 8:63-73; 2005. 


\section{RCAN1 and Exhaustive Exercise June 18, 2015 Revision}

10. Ermak, G.; Davies, K. J. Chronic high levels of the RCAN1-1 protein may promote neurodegeneration and Alzheimer disease. Free Radic. Biol. Med. 62:47-51; 2013.

11. Harris, C. D.; Ermak, G.; Davies, K. J. Multiple roles of the DSCR1 (Adapt78 or RCAN1) gene and its protein product calcipressin 1 (or RCAN1) in disease. Cell. Mol. Life Sci. 62:2477-2486; 2005.

12. Ermak, G.; Hench, K. J.; Chang, K. T.; Sachdev, S.; Davies, K. J. Regulator of calcineurin (RCAN1-1L) is deficient in Huntington disease and protective against mutant huntingtin toxicity in vitro. J. Biol. Chem. 284:11845-11853; 2009.

13. Ermak, G.; Harris, C. D.; Davies, K. J. The DSCR1 (Adapt78) isoform 1 protein calcipressin 1 inhibits calcineurin and protects against acute calcium-mediated stress damage, including transient oxidative stress. FASEB J. 16:814-824; 2002.

14. Leahy, K.P.; Crawford, D.R. Adapt78 protects cells against stress damage and suppresses cell growth. Arch. Biochem. Biophys. 379:221-228; 2000.

15. Lin, H. Y.; Michtalik, H. J.; Zhang, S.; Andersen, T. T.; Van Riper, D. A.; Davies, K. K.; Ermak, G.; Petti, L. M.; Nachod, S.; Narayan, A. V.; Bhatt, N.; Crawford, D. R. Oxidative and calcium stress regulate DSCR1 (Adapt78/MCIP1) protein. Free Radic. Biol. Med. 35:528-539; 2003. 


\section{RCAN1 and Exhaustive Exercise June 18, 2015 Revision}

16. Ermak, G.; Pritchard, M. A.; Dronjak, S.; Niu, B.; Davies, K. J. Do RCAN1 proteins link chronic stress with neurodegeneration? FASEB J. 25:3306-3311; 2011.

17. Wang, Y.; De Keulenaer, G. W.; Weinberg, E. O.; Muangman, S.; Gualberto, A.; Landschulz, K. T.; Turi, T. G.; Thompson, J. F.; Lee, R. T. Direct biomechanical induction of endogenous calcineurin inhibitor Down Syndrome Critical Region-1 in cardiac myocytes. Am. J. Physiol. Heart Circ. Physiol. 283:H533-539; 2002.

18. Poulsen, H. E.; Weimann, A.; Loft, S. Methods to detect DNA damage by free radicals: relation to exercise. Proc. Nutr. Soc. 58:1007-1014; 1999.

19. Morton, J. P.; Kayani, A. C.; McArdle, A.; Drust, B. The exercise-induced stress response of skeletal muscle, with specific emphasis on humans. Sports Med. 39:643$662 ; 2009$.

20. Gomez-Cabrera, M. C.; Borras, C.; Pallardo, F. V.; Sastre, J.; Ji, L. L.; Vina, J. Decreasing xanthine oxidase-mediated oxidative stress prevents useful cellular adaptations to exercise in rats. J. Physiol. 567:113-120; 2005.

21. Sastre, J.; Asensi, M.; Gasco, E.; Pallardo, F. V.; Ferrero, J. A.; Furukawa, T.; Vina, J. Exhaustive physical exercise causes oxidation of glutathione status in blood: prevention by antioxidant administration. Am. J. Physiol. 263:R992-995; 1992.

22. Egan, B.; Zierath, J. R. Exercise metabolism and the molecular regulation of skeletal muscle adaptation. Cell Metab. 17:162-184; 2013. 


\section{RCAN1 and Exhaustive Exercise June 18, 2015 Revision}

23. Davies, K. J.; Quintanilha, A. T.; Brooks, G. A.; Packer, L. Free radicals and tissue damage produced by exercise. Biochem. Biophys. Res. Commun. 107:1198-1205; 1982.

24. Malaguti, M.; Angeloni, C.; Garatachea, N.; Baldini, M.; Leoncini, E.; Collado, P. S.; Teti, G.; Falconi, M.; Gonzalez-Gallego, J.; Hrelia, S. Sulforaphane treatment protects skeletal muscle against damage induced by exhaustive exercise in rats. J. Appl. Physiol. (1985) 107:1028-1036; 2009.

25. Chin, E. R.; Olson, E. N.; Richardson, J. A.; Yang, Q.; Humphries, C.; Shelton, J. M.; Wu, H.; Zhu, W.; Bassel-Duby, R.; Williams, R. S. A calcineurin-dependent transcriptional pathway controls skeletal muscle fiber type. Genes Dev. 12:2499-2509; 1998.

26. Staron, R. S. Human skeletal muscle fiber types: delineation, development, and distribution. Can. J. Appl. Physiol. 22:307-327; 1997.

27. Macintosh, B. R.; Gardiner, P. F.; McComas, A. J., eds. Skeletal muscle: form and function. Champaign: Human kinetics; 2006.

28. Ji, L. L.; Fu, R.; Mitchell, E. W. Glutathione and antioxidant enzymes in skeletal muscle: effects of fiber type and exercise intensity. J. Appl. Physiol. (1985) 73:1854$1859 ; 1992$. 


\section{RCAN1 and Exhaustive Exercise June 18, 2015 Revision}

29. Nonaka, K.; Une, S.; Tatsuta, N.; Ito, K.; Akiyama, J. Changes in antioxidant enzymes and lipid peroxidation in extensor digitorum longus muscles of streptozotocin-diabetic rats may contribute to muscle atrophy. Acta Physiol. Hung. 101:421-428; 2014.

30. Bueno, O. F.; Brandt, E. B.; Rothenberg, M. E.; Molkentin, J. D. Defective T cell development and function in calcineurin A beta -deficient mice. Proc. Natl. Acad. Sci. U S A 99:9398-9403; 2002.

31. Arron, J. R.; Winslow, M. M.; Polleri, A.; Chang, C. P.; Wu, H.; Gao, X.; Neilson, J. R.; Chen, L.; Heit, J. J.; Kim, S. K.; Yamasaki, N.; Miyakawa, T.; Francke, U.; Graef, I. A.; Crabtree, G. R. NFAT dysregulation by increased dosage of DSCR1 and DYRK1A on chromosome 21. Nature 441:595-600; 2006.

32. Batiuk, T. D.; Halloran, P. F. The downstream consequences of calcineurin inhibition. Transplant Proc. 29:1239-1240; 1997.

33. Kim, H. B.; Kong, M.; Kim, T. M.; Suh, Y. H.; Kim, W. H.; Lim, J. H.; Song, J. H.; Jung, M. H. NFATc4 and ATF3 negatively regulate adiponectin gene expression in 3T3-L1 adipocytes. Diabetes 55:1342-1352; 2006.

34. Yamauchi, T.; Kamon, J.; Waki, H.; Terauchi, Y.; Kubota, N.; Hara, K.; Mori, Y.; Ide, T.; Murakami, K.; Tsuboyama-Kasaoka, N.; Ezaki, O.; Akanuma, Y.; Gavrilova, O.; Vinson, C.; Reitman, M. L.; Kagechika, H.; Shudo, K.; Yoda, M.; Nakano, Y.; Tobe, 


\section{RCAN1 and Exhaustive Exercise June 18, 2015 Revision}

K.; Nagai, R.; Kimura, S.; Tomita, M.; Froguel, P.; Kadowaki, T. The fat-derived hormone adiponectin reverses insulin resistance associated with both lipoatrophy and obesity. Nat. Med. 7:941-946; 2001.

35. Punyadeera, C.; Zorenc, A. H.; Koopman, R.; McAinch, A. J.; Smit, E.; Manders, R.; Keizer, H. A.; Cameron-Smith, D.; van Loon, L. J. The effects of exercise and adipose tissue lipolysis on plasma adiponectin concentration and adiponectin receptor expression in human skeletal muscle. Eur. J. Endocrinol. 152:427-436; 2005.

36. Zierath, J. R.; Hawley, J. A. Skeletal muscle fiber type: influence on contractile and metabolic properties. PLoS Biol. 2:e348; 2004.

37. Bradford, M. M. A rapid and sensitive method for the quantitation of microgram quantities of protein utilizing the principle of protein-dye binding. Anal. Biochem. 72:248-254; 1976.

38. Fehrenbach, E.; Passek, F.; Niess, A. M.; Pohla, H.; Weinstock, C.; Dickhuth, H. H.; Northoff, H. HSP expression in human leukocytes is modulated by endurance exercise. Med. Sci. Sports Exerc. 32:592-600; 2000.

39. Levine, R. L.; Garland, D.; Oliver, C. N.; Amici, A.; Climent, I.; Lenz, A. G.; Ahn, B. W.; Shaltiel, S.; Stadtman, E. R. Determination of carbonyl content in oxidatively modified proteins. Methods Enzymol. 186:464-478; 1990. 


\section{RCAN1 and Exhaustive Exercise June 18, 2015 Revision}

40. Armstrong, D.; Browne, R. The analysis of free radicals, lipid peroxides, antioxidant enzymes and compounds related to oxidative stress as applied to the clinical chemistry laboratory. Adv. Exp. Med. Biol. 366:43-58; 1994.

41. Yagi, K. Simple assay for the level of total lipid peroxides in serum or plasma. Methods Mol. Biol. 108:101-106; 1998.

42. Graef, I. A.; Chen, F.; Chen, L.; Kuo, A.; Crabtree, G. R. Signals transduced by $\mathrm{Ca}(2+) /$ calcineurin and NFATc3/c4 pattern the developing vasculature. Cell 105:863$875 ; 2001$.

43. Martin, B.; Pallen, C. J.; Wang, J. H.; Graves, D. J. Use of fluorinated tyrosine phosphates to probe the substrate specificity of the low molecular weight phosphatase activity of calcineurin. J. Biol. Chem. 260:14932-14937; 1985.

44. Calabria, E.; Ciciliot, S.; Moretti, I.; Garcia, M.; Picard, A.; Dyar, K. A.; Pallafacchina, G.; Tothova, J.; Schiaffino, S.; Murgia, M. NFAT isoforms control activity-dependent muscle fiber type specification. Proc. Natl. Acad. Sci. U S A 106:13335-13340; 2009.

45. Hogan, P. G.; Chen, L.; Nardone, J.; Rao, A. Transcriptional regulation by calcium, calcineurin, and NFAT. Genes Dev. 17:2205-2232; 2003.

46. Porta, S.; Serra, S. A.; Huch, M.; Valverde, M. A.; Llorens, F.; Estivill, X.; Arbones, M. L.; Marti, E. RCAN1 (DSCR1) increases neuronal susceptibility to oxidative stress: a potential pathogenic process in neurodegeneration. Hum. Mol. Genet. 16:1039-1050; 2007. 


\section{RCAN1 and Exhaustive Exercise June 18, 2015 Revision}

47. Seo, S. R.; Kim, S. S.; Chung, K. C. Activation of adenylate cyclase by forskolin increases the protein stability of RCAN1 (DSCR1 or Adapt78). FEBS Lett. 583:31403144; 2009.

48. Mahoney, D. J.; Safdar, A.; Parise, G.; Melov, S.; Fu, M.; MacNeil, L.; Kaczor, J.; Payne, E. T.; Tarnopolsky, M. A. Gene expression profiling in human skeletal muscle during recovery from eccentric exercise. Am. J. Physiol. Regul. Integr. Comp. Physiol. 294:R1901-1910; 2008.

49. Reid, M. B.; Khawli, F. A.; Moody, M. R. Reactive oxygen in skeletal muscle. III. Contractility of unfatigued muscle. J. Appl. Physiol. (1985) 75:1081-1087; 1993.

50. Vasilaki, A.; Csete, M.; Pye, D.; Lee, S.; Palomero, J.; McArdle, F.; Van Remmen, H.; Richardson, A.; McArdle, A.; Faulkner, J. A.; Jackson, M. J. Genetic modification of the manganese superoxide dismutase/glutathione peroxidase 1 pathway influences intracellular ROS generation in quiescent, but not contracting, skeletal muscle cells. Free Radic. Biol. Med. 41:1719-1725; 2006.

51. Popovic, L. M.; Mitic, N. R.; Radic, I.; Miric, D.; Kisic, B.; Krdzic, B.; Djokic, T. The effect of exhaustive exercise on oxidative stress generation and antioxidant defense in guinea pigs. Adv. Clin. Exp. Med. 21:313-320; 2012. 


\section{RCAN1 and Exhaustive Exercise June 18, 2015 Revision}

52. Anderstam, B.; Ann-Christin, B. H.; Valli, A.; Stenvinkel, P.; Lindholm, B.; Suliman, M. E. Modification of the oxidative stress biomarker AOPP assay: application in uremic samples. Clin. Chim. Acta 393:114-118; 2008.

53. Kaneda, H.; Taguchi, J.; Ogasawara, K.; Aizawa, T.; Ohno, M. Increased level of advanced oxidation protein products in patients with coronary artery disease. Atherosclerosis 162:221-225; 2002.

54. Piwowar, A.; Knapik-Kordecka, M.; Warwas, M. AOPP and its relations with selected markers of oxidative/antioxidative system in type 2 diabetes mellitus. Diabetes Res. Clin. Pract. 77:188-192; 2007.

55. Yamano, S.; Eto, D.; Hiraga, A.; Miyata, H. Recruitment pattern of muscle fibre type during high intensity exercise (60-100\% VO2max) in thoroughbred horses. Res. Vet. Sci. 80:109-115; 2006.

56. Fugere, N. A.; Ferrington, D. A.; Thompson, L. V. Protein nitration with aging in the rat semimembranosus and soleus muscles. J. Gerontol. A Biol. Sci. Med. Sci. 61:806$812 ; 2006$.

57. Xu, X.; Chen, C. N.; Arriaga, E. A.; Thompson, L. V. Asymmetric superoxide release inside and outside the mitochondria in skeletal muscle under conditions of aging and disuse. J. Appl. Physiol. (1985) 109:1133-1139; 2010.

58. Lin, J.; Wu, H.; Tarr, P. T.; Zhang, C. Y.; Wu, Z.; Boss, O.; Michael, L. F.; Puigserver, P.; Isotani, E.; Olson, E. N.; Lowell, B. B.; Bassel-Duby, R.; Spiegelman, 


\section{RCAN1 and Exhaustive Exercise June 18, 2015 Revision}

B. M. Transcriptional co-activator PGC-1 alpha drives the formation of slow-twitch muscle fibres. Nature 418:797-801; 2002.

59. Arany, Z. PGC-1 coactivators and skeletal muscle adaptations in health and disease. Curr. Opin. Genet. Dev. 18:426-434; 2008.

60. Mootha, V. K.; Lindgren, C. M.; Eriksson, K. F.; Subramanian, A.; Sihag, S.; Lehar, J.; Puigserver, P.; Carlsson, E.; Ridderstrale, M.; Laurila, E.; Houstis, N.; Daly, M. J.; Patterson, N.; Mesirov, J. P.; Golub, T. R.; Tamayo, P.; Spiegelman, B.; Lander, E. S.; Hirschhorn, J. N.; Altshuler, D.; Groop, L. C. PGC-1alpha-responsive genes involved in oxidative phosphorylation are coordinately downregulated in human diabetes. Nat. Genet. 34:267-273; 2003.

61. Patti, M. E.; Butte, A. J.; Crunkhorn, S.; Cusi, K.; Berria, R.; Kashyap, S.; Miyazaki, Y.; Kohane, I.; Costello, M.; Saccone, R.; Landaker, E. J.; Goldfine, A. B.; Mun, E.; DeFronzo, R.; Finlayson, J.; Kahn, C. R.; Mandarino, L. J. Coordinated reduction of genes of oxidative metabolism in humans with insulin resistance and diabetes: Potential role of PGC1 and NRF1. Proc. Natl. Acad. Sci. U S A 100:8466-8471; 2003.

62. Adhihetty, P. J.; Irrcher, I.; Joseph, A. M.; Ljubicic, V.; Hood, D. A. Plasticity of skeletal muscle mitochondria in response to contractile activity. Exp. Physiol. 88:99$107 ; 2003$. 


\section{RCAN1 and Exhaustive Exercise June 18, 2015 Revision}

63. Befroy, D. E.; Petersen, K. F.; Dufour, S.; Mason, G. F.; Rothman, D. L.; Shulman, G.

I. Increased substrate oxidation and mitochondrial uncoupling in skeletal muscle of endurance-trained individuals. Proc. Natl. Acad. Sci. U S A 105:16701-16706; 2008.

64. Koulmann, N.; Banzet, S.; Sanchez, H.; Chapot, R.; Serrurier, B.; Simler, N.; Peinnequin, A.; Bigard, X. Exercise-induced PGC-1 alpha mRNA increase is independent on calcineurin activation in skeletal muscle of rats. FASEB J. 21, LB116; 2007.

65. Dai, Y.; Pang, J.; Gong, H.; Fan, W.; Zhang, T. M. Roles and tissue source of adiponectin involved in lifestyle modifications. J. Gerontol. A Biol. Sci. Med. Sci. 68:117-128; 2013.

66. Pereira, M. J.; Palming, J.; Rizell, M.; Aureliano, M.; Carvalho, E.; Svensson, M. K.; Eriksson, J. W. Cyclosporine A and tacrolimus reduce the amount of GLUT4 at the cell surface in human adipocytes: increased endocytosis as a potential mechanism for the diabetogenic effects of immunosuppressive agents. J. Clin. Endocrinol. Metab. 99:E1885-1894; 2014.

\section{Figure legends}

- Fig. 1. Effect of exhaustive exercise on the levels of RCAN1 protein isoforms in rat skeletal muscles. For each muscle, immunoblots of RCAN1 against our common antiRCAN1 antibody revealed three expressed isoforms: RCAN1-1L (36KDa ), RCAN11S (32KDa) and RCAN1-4 (25KDa). Levels of RCAN1 isoforms A) in EDL, B) in gastrocnemius and C) in soleus. HSC70 was used as a loading control in all the immunoblots. Results are expressed as mean values \pm SEM's of 5 rats per group, corrected for loading errors by HSC70 levels. Statistically significant differences were 


\section{RCAN1 and Exhaustive Exercise June 18, 2015 Revision}

tested by ANOVA at the $p<0.05$ level, and are indicated in the figures by asteriscs $(*)$.

- Fig 2. Effect of exhaustive exercise on markers of oxidative stress in rat skeletal muscle. A) Protein oxidation was assayed spectrophotometrically by analysis of carbonyl content at $355 \mathrm{~nm}$ in samples prepared from EDL, gastrocnemius and soleus muscle. B) lipid peroxidation was estimated in the same muscles by formation of thiobarbituric acid reactive substances (including malondialdehyde). Both techniques are described in Materials \& Methods. Results are expressed as mean values \pm SEM's of 5 rats per group. Statistically significant differences were tested by ANOVA and are indicated in the figures by single asteriscs $\left(^{*}\right)$ at the $\mathrm{p}<0.05$ level.

- Fig. 3. Effect of exhaustive exercise on the levels of CuZn Superoxide Dismutase in rat skeletal muscles. CuZnSOD levels were assayed in EDL, gastrocnemius, and soleus by immunoblot, as described in Materials \& Methods. Representative immunoblots are shown in the upper panels for each muscle, and average protein levels are shown for each muscle in the bar graphs. HSC70 was used as a loading control in all the immunoblots. Results are expressed as mean values \pm SEM's of 5 rats per group, corrected for loading errors by HSC70 levels. Statistically significant differences were tested by ANOVA at the $\mathrm{p}<0.05$ level, and are indicated in the figures by asteriscs $(*)$.

- Fig. 4. Effect of exhaustive exercise on the levels of Catalase in rat skeletal muscles. Catalase protein levels were assayed in EDL, gastrocnemius, and soleus by immunoblot, as described in Materials \& Methods. Representative immunoblots are shown in the upper panels for each muscle, and average protein levels are shown for each muscle in the bar graphs. HSC70 was used as a loading control in all the immunoblots. Results are expressed as mean values \pm SEM's of 5 rats per group, corrected for loading errors by HSC70 levels. Statistically significant differences were 


\section{RCAN1 and Exhaustive Exercise June 18, 2015 Revision}

tested by ANOVA at the $p<0.05$ level, and are indicated in the figures by asteriscs $(*)$.

- Fig. 5. Effect of exhaustive exercise on the levels of Glutathione Peroxidase and MnSOD protein levels in rat skeletal muscles. Glutathione Peroxidase (A) and MnSOD (B) protein levels were assayed in EDL, gastrocnemius, and soleus by immunoblot, as described in Materials \& Methods. Representative immunoblots are shown for each muscle. HSC70 was used as a loading control in all the immunoblots.

- Fig. 6. Effect of exhaustive exercise on the protein levels and enzymatic activity of calcineurin in rat skeletal muscles. Calcineurin protein levels and activity A) in EDL, B) in gastrocnemius and C) in soleus. Results are expressed as mean values \pm SEM's of 5 rats per group, with calcineurin protein corrected for loading errors by HSC70 levels. Calcineurin enzymatic activity was measured as described in Materials \& Methods. Statistically significant differences were tested by ANOVA at the $p<0.05$ level, and are indicated in the figures by asteriscs (*).

- Fig. 7. Effect of exhaustive exercise on the levels of PGC1- $\alpha$ protein in rat skeletal muscle. PGC1- $\alpha$ protein levels were measured in EDL, gastrocnemius, and soleus by immunoblot, as described in Materials \& Methods. HSC70 was used as a loading control in all the immunoblots. Results are expressed as mean values \pm SEM's of 5 rats per group, corrected for loading errors by HSC70 levels. Statistically significant differences were tested by ANOVA at the $\mathrm{p}<0.05$ level, and are indicated in the figures by asteriscs $(*)$.

- Fig. 8. Effect of exhaustive exercise on the levels of NFAT isoforms in rat skeletal muscles. The upper panels show representative immunoblots for NFATc4 in EDL, gastrocnemius and soleus muscles. Then lower panels show the average levels of NFATc4. HSC70 was used as an equal loading control in all the immunoblots. Results 


\section{RCAN1 and Exhaustive Exercise June 18, 2015 Revision}

are expressed as mean values \pm SEM's of 5 rats per group, corrected for loading errors by HSC70 levels. Statistically significant differences were tested by ANOVA and are indicated in the figures by single asteriscs $(*)$ at the $\mathrm{p}<0.05$ level

- Fig. 9. Effect of exhaustive exercise on the levels of Adiponectin in rat skeletal muscles. The upper panels show representative immunoblots for adiponectin in soleus, gastrocnemius and EDL muscles. Then lower panels show the average levels of adiponectin . HSC70 was used as an equal loading control in all the immunoblots. Results are expressed as mean values \pm SEM's of 5 rats per group, corrected for loading errors by HSC70 levels. Statistically significant differences were tested by ANOVA and are indicated in the figures by single asteriscs $(*)$ at the $\mathrm{p}<0.05$ level.

\section{Highlights}

- Exhaustive exercise increases oxidative damage and RCAN1-4 expression in muscles

- Up regulation of RCAN1-4 decreases calcineurin activity

- NFATc4 is downregulated and adiponectin is increased in muscles after exercise

- RCAN1-4 represents an important component of physiological adaptation to exercise 
RCAN1 and Exhaustive Exercise June 16, 2015 Revision

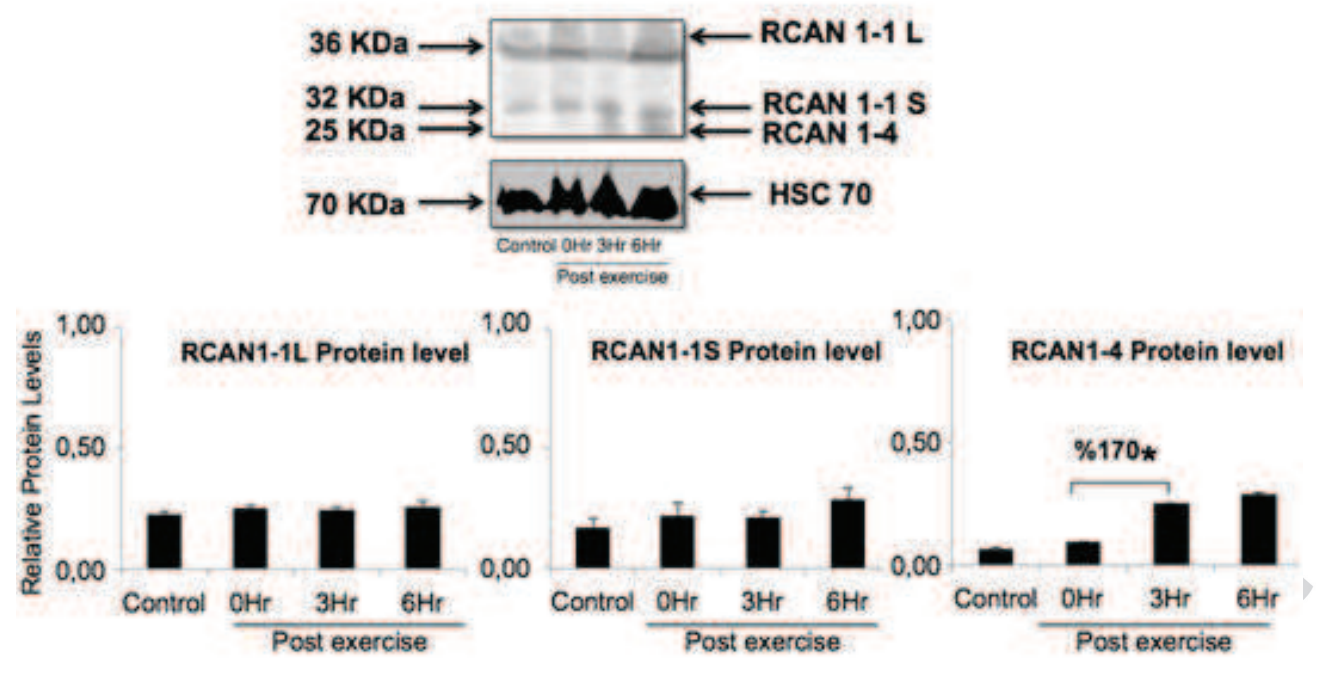

B
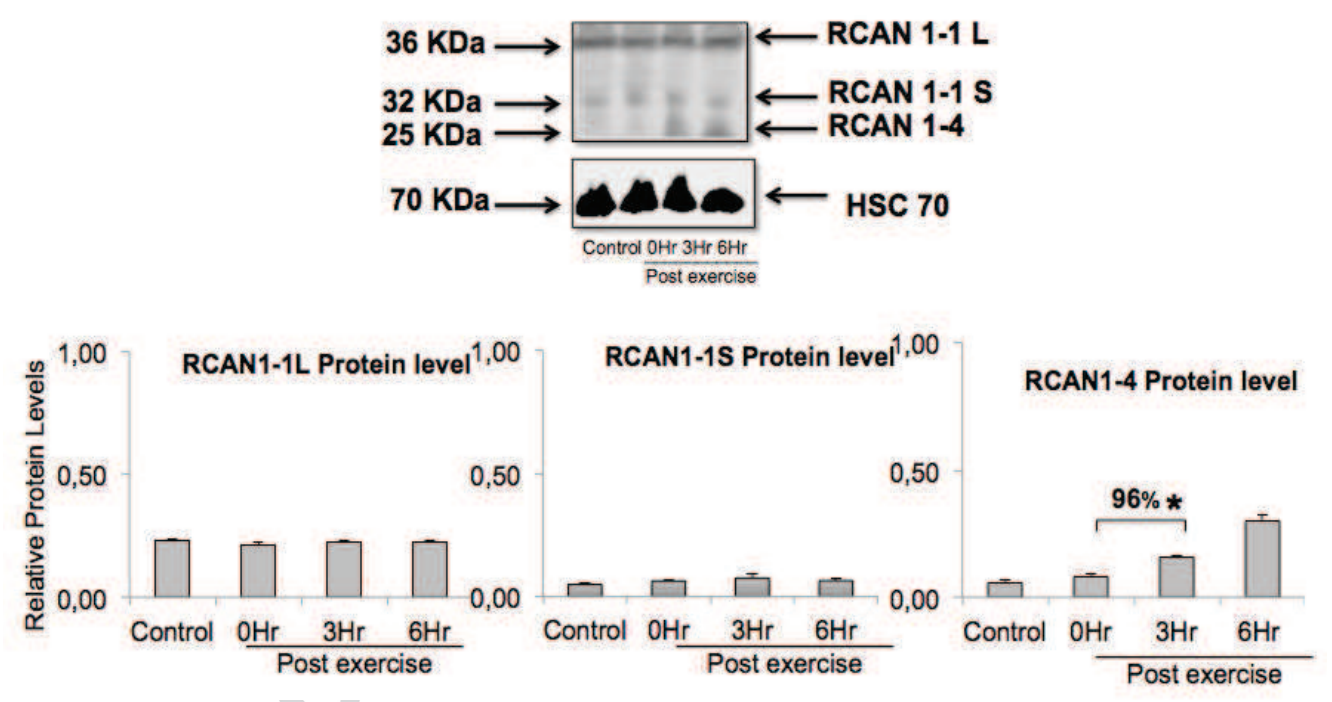

C
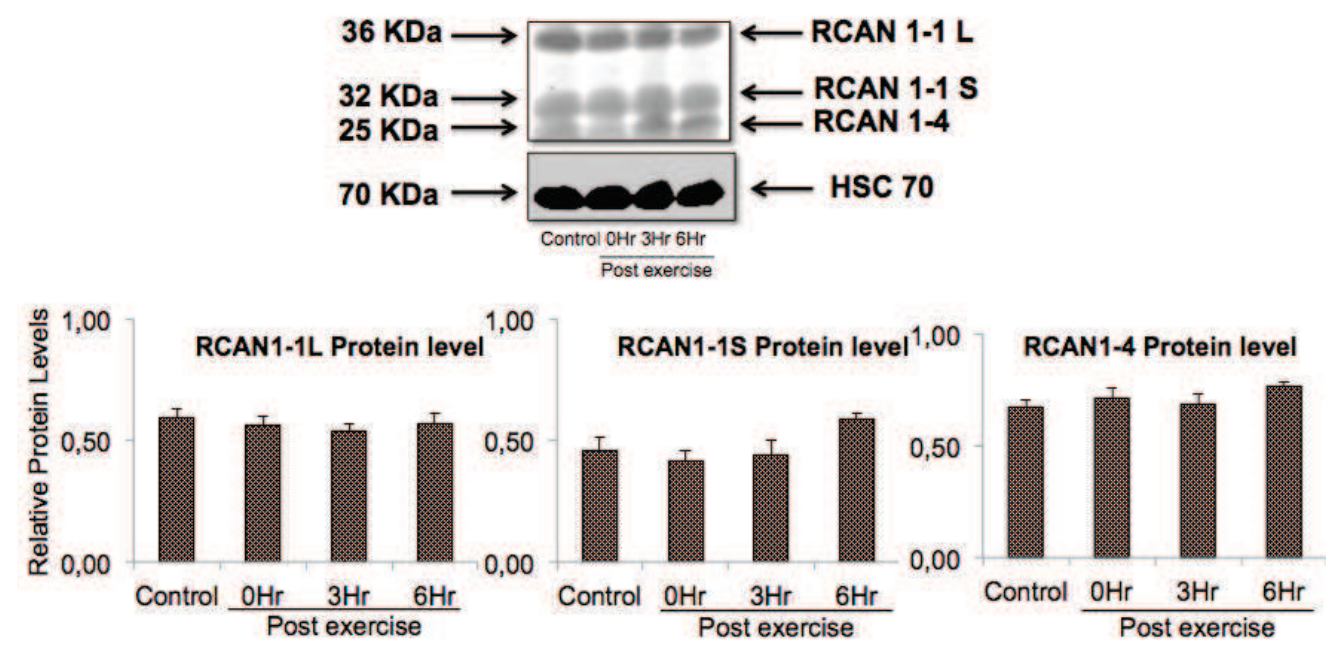
RCAN1 and Exhaustive Exercise June 16, 2015 Revision

FIGURE 2
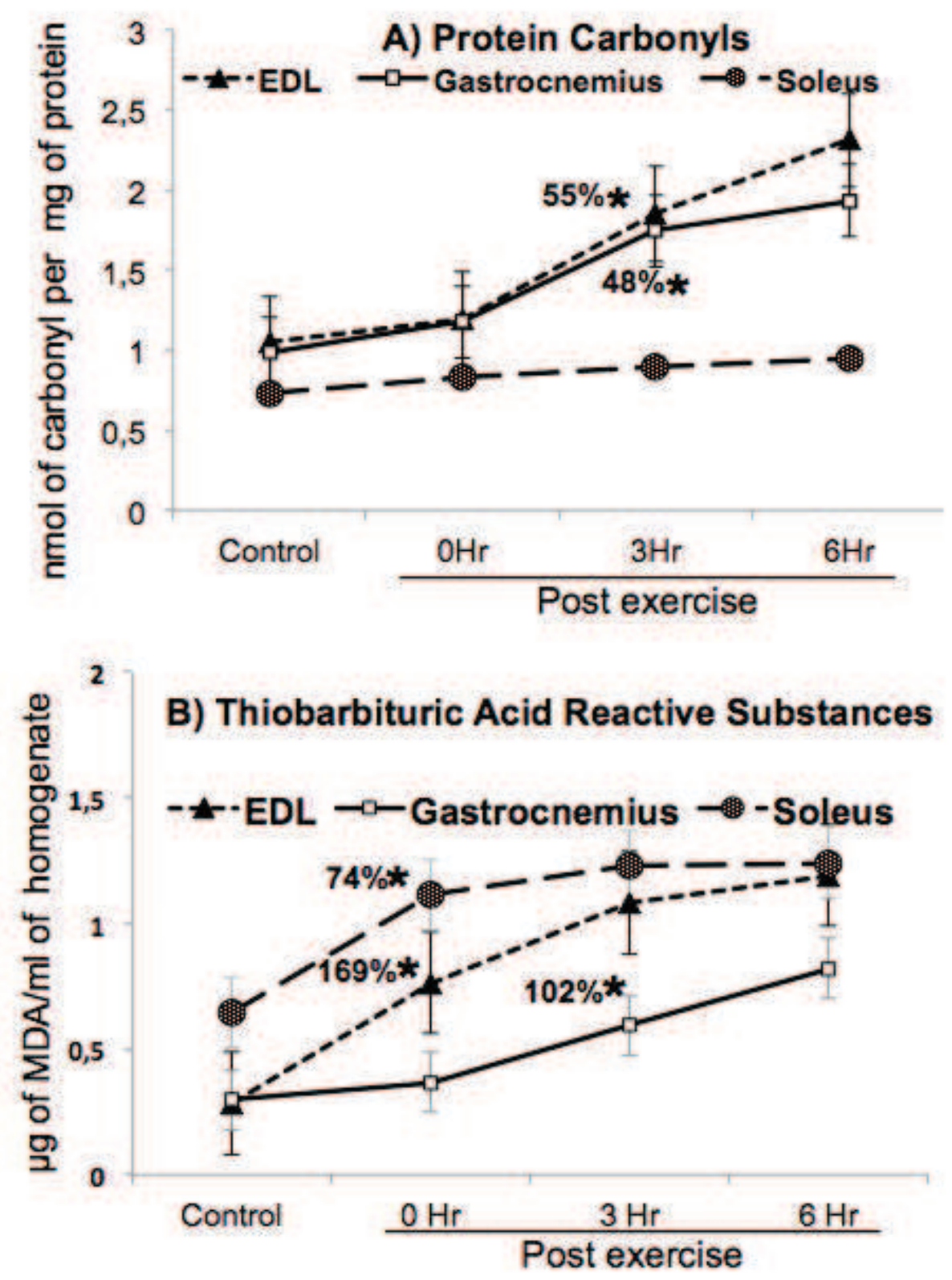
RCAN1 and Exhaustive Exercise June 16, 2015 Revision

FIGURE 3
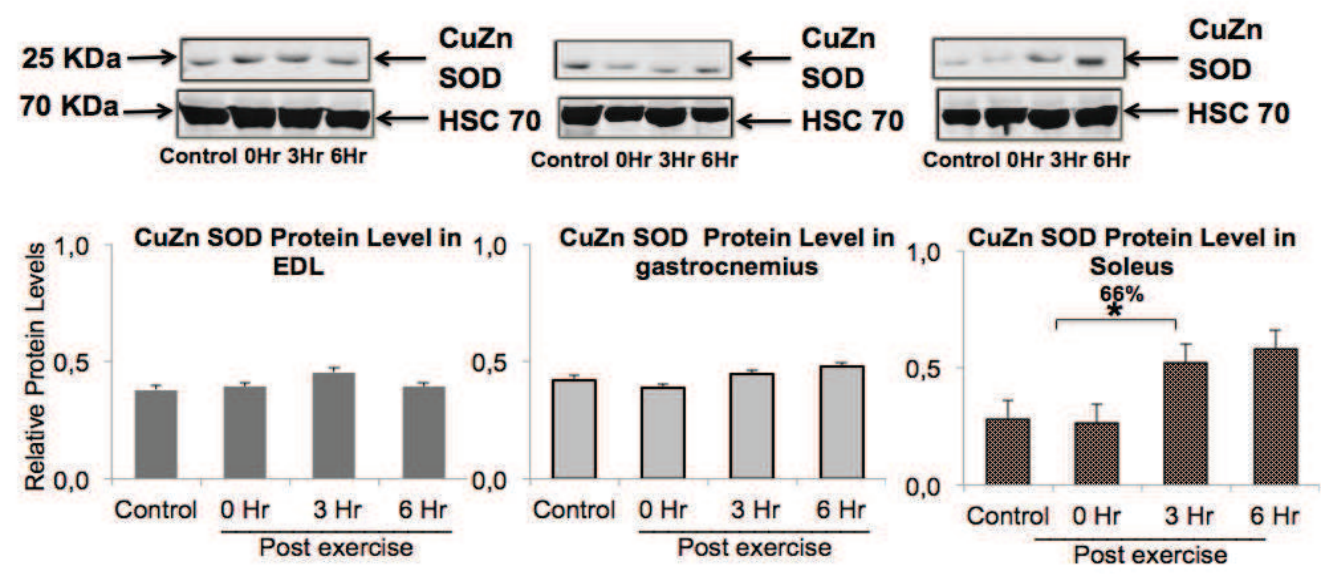
RCAN1 and Exhaustive Exercise June 16, 2015 Revision

FIGURE 4

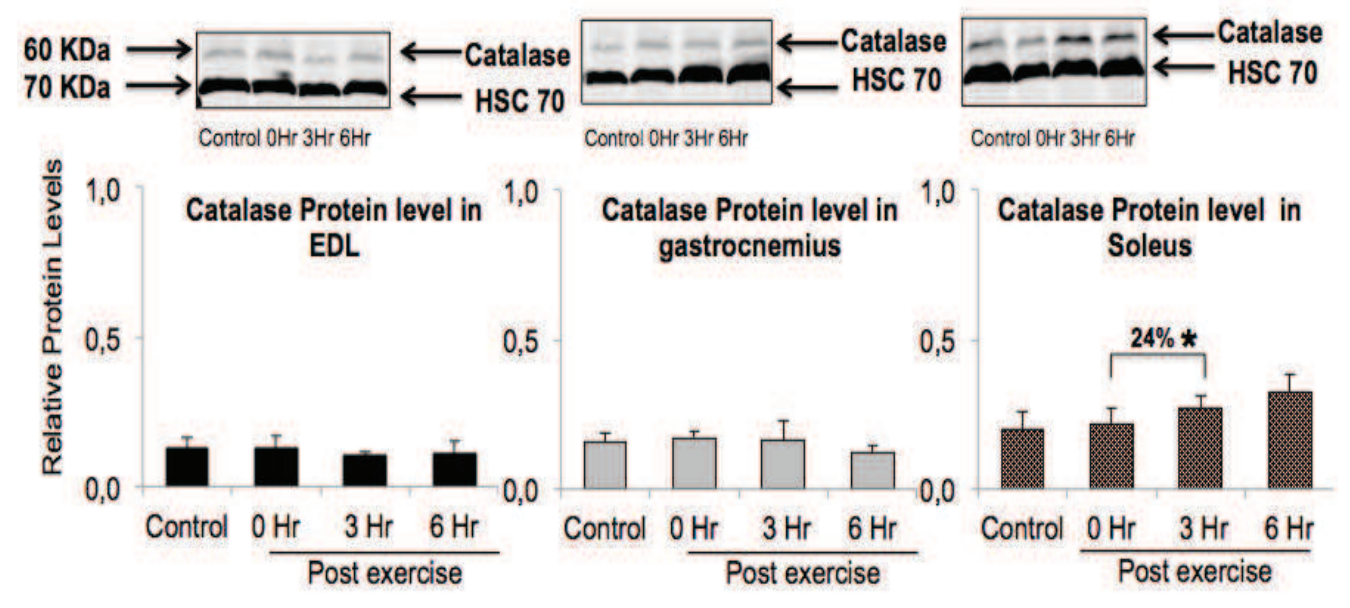


RCAN1 and Exhaustive Exercise June 16, 2015 Revision

FIGURE 5
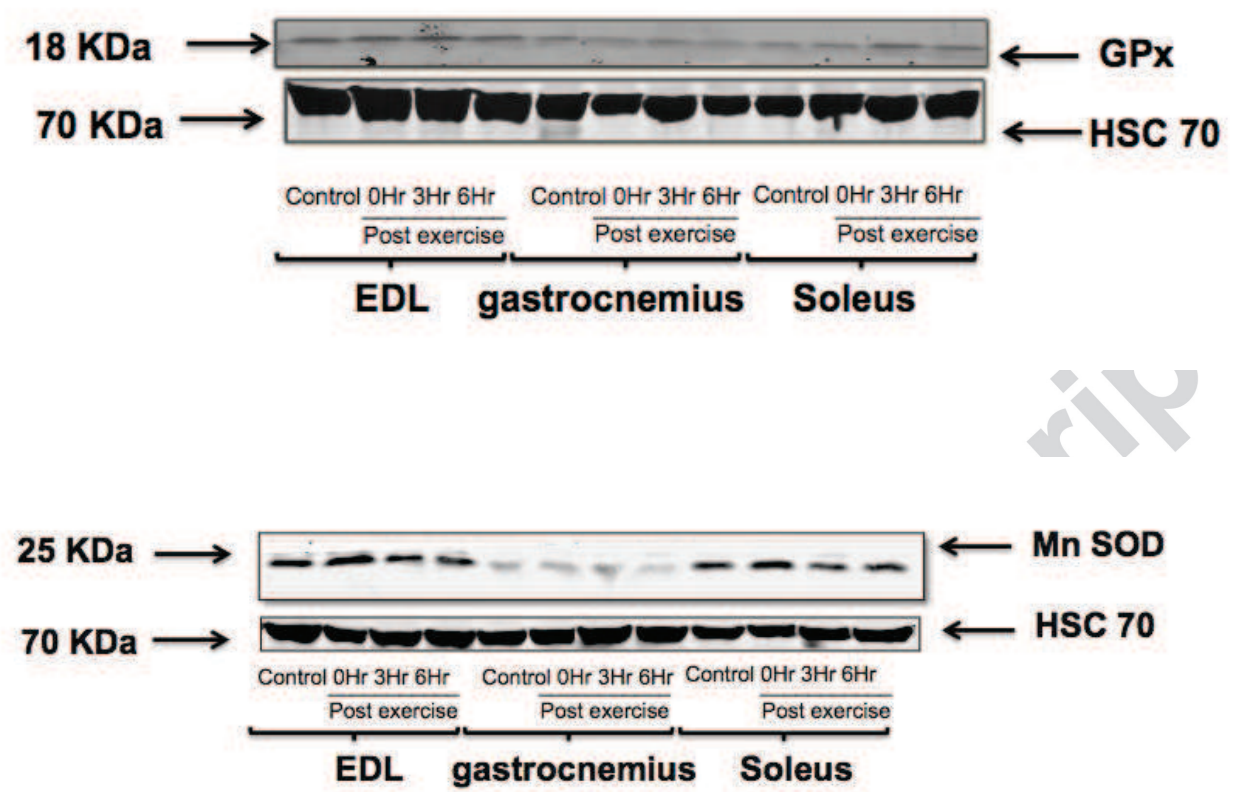
RCAN1 and Exhaustive Exercise June 16, 2015 Revision

FIGURE 4

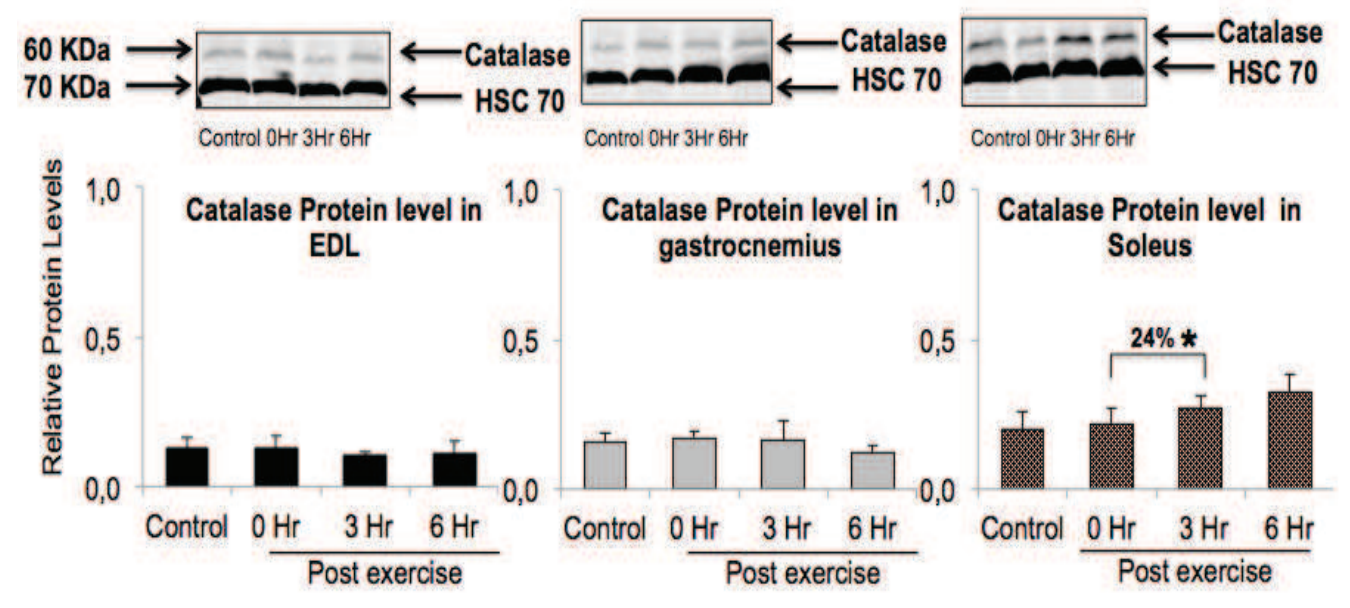


RCAN1 and Exhaustive Exercise June 16, 2015 Revision

FIGURE 7
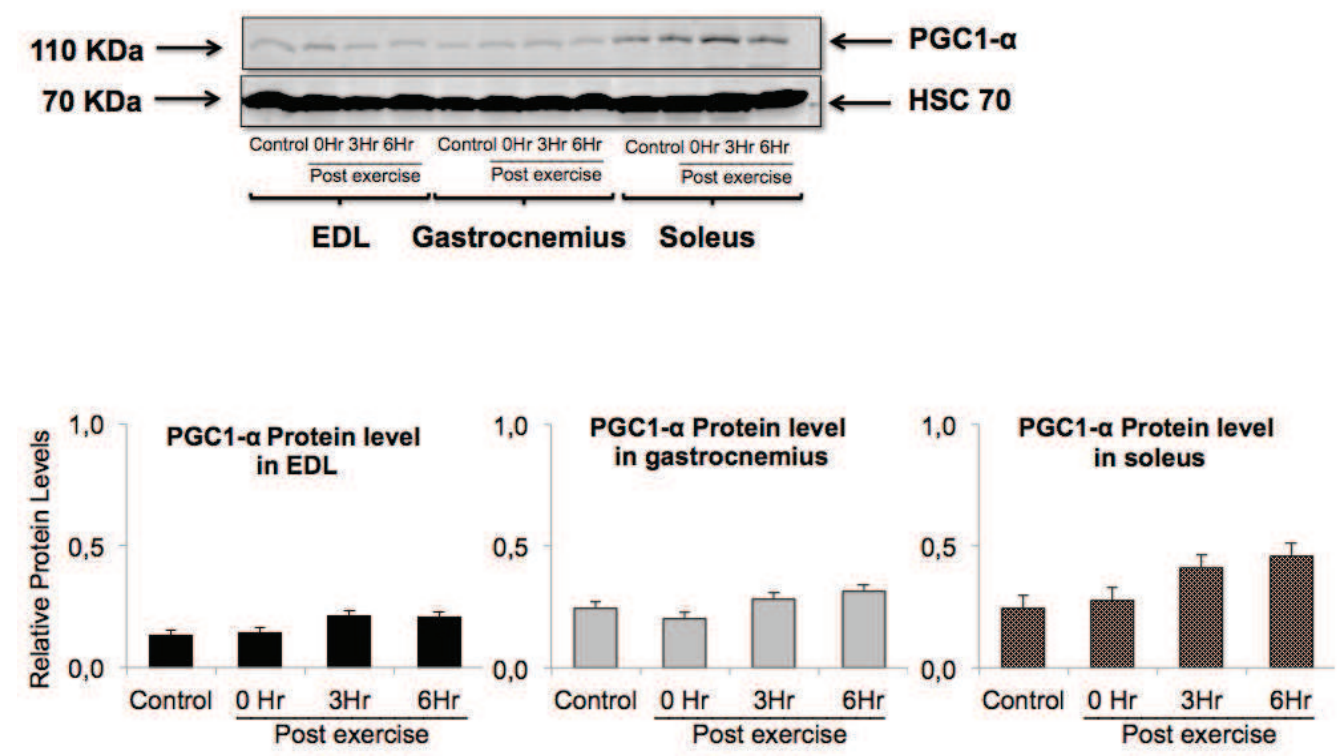
RCAN1 and Exhaustive Exercise June 16, 2015 Revision

FIGURE 8
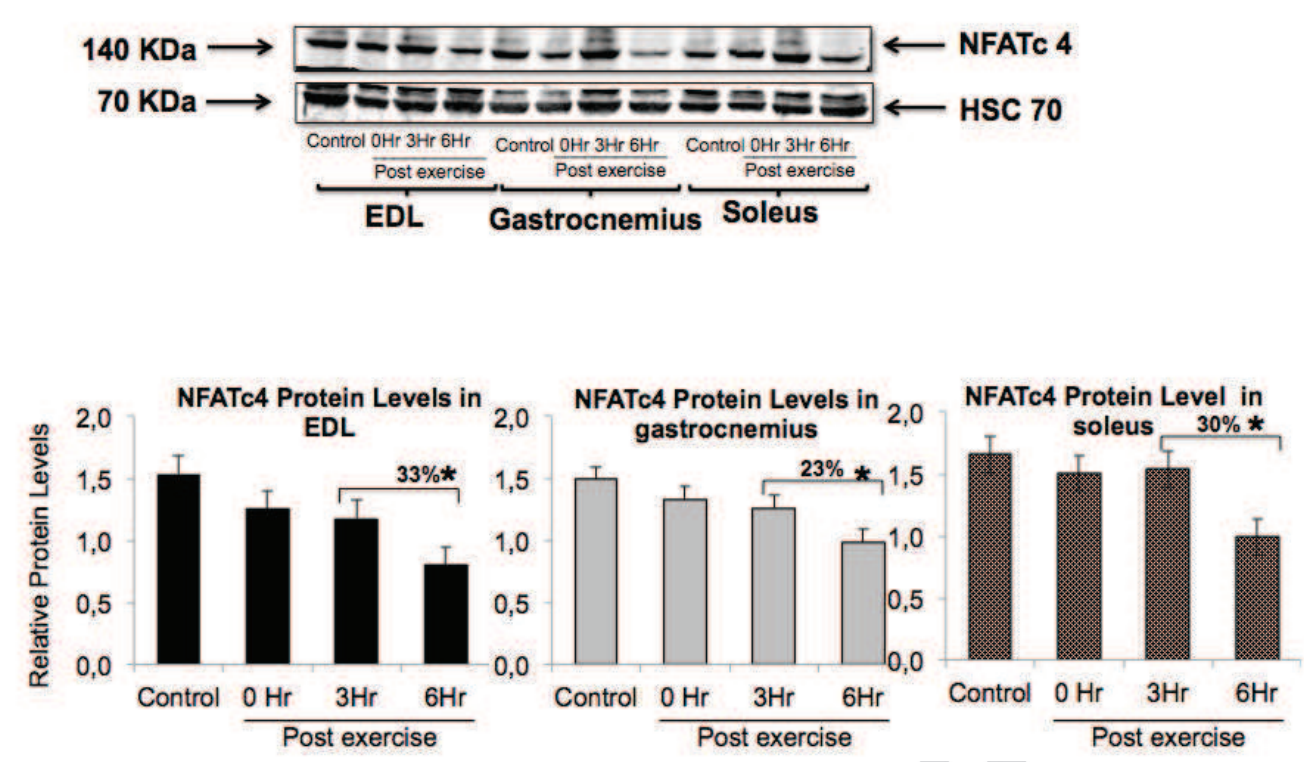
RCAN1 and Exhaustive Exercise June 16, 2015 Revision

FIGURE 9

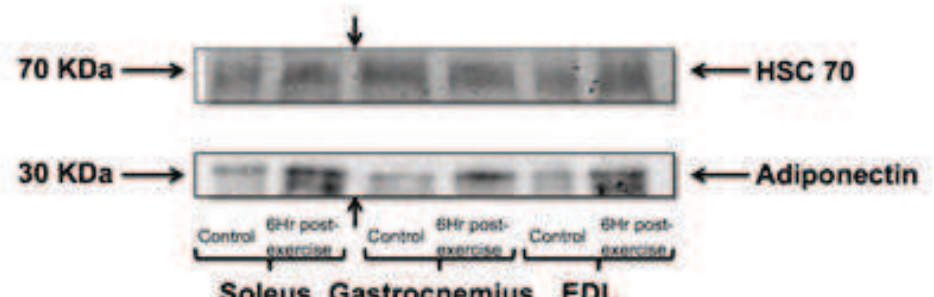

Soleus Gastrocnemius EDL
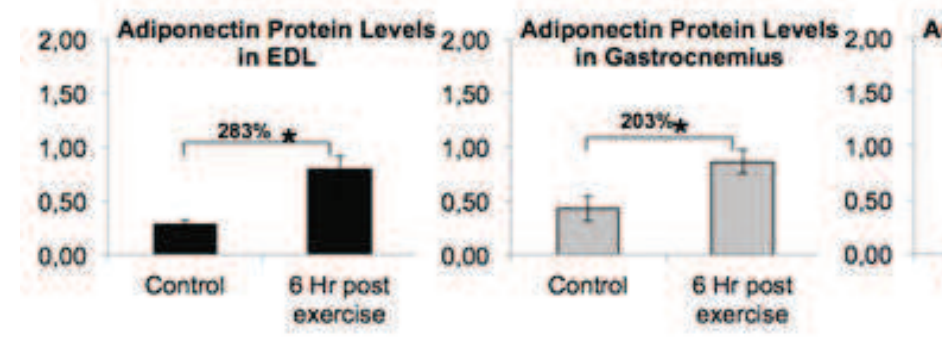

Adiponectin Protein Levels

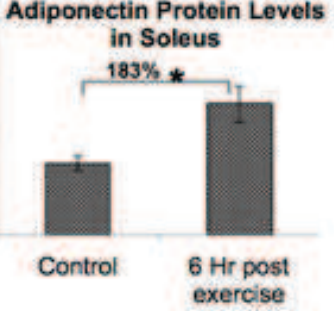




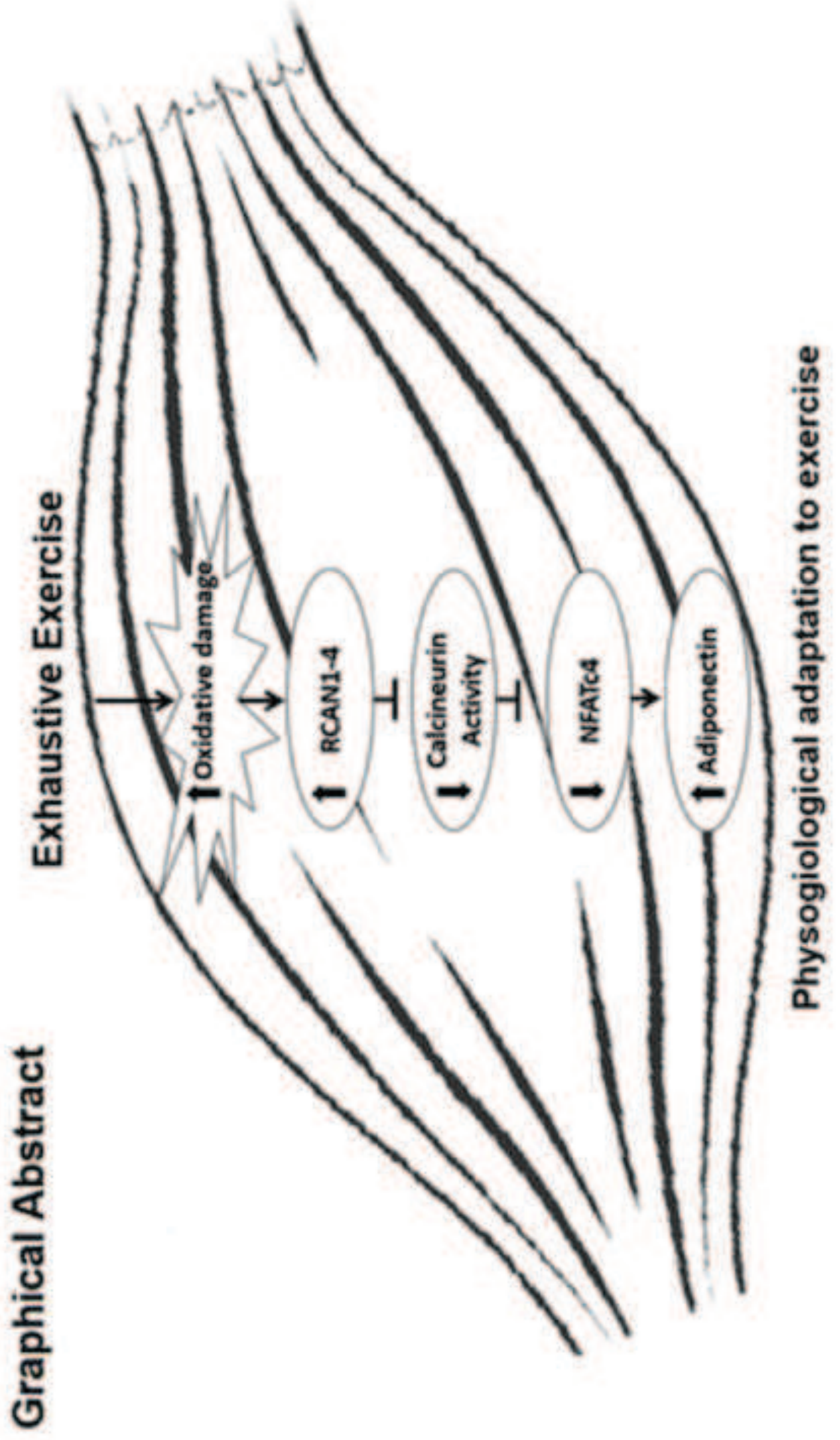

